\title{
Elektron kitabxanalarda fərdi məlumatların təhlükəsizliyi məsələləri
}

\author{
Firudin Osgərov ${ }^{1}$, Rəhilə Həsənova ${ }^{2}$ \\ ${ }^{1,2}$ AMEA İnformasiya Texnologiyaları İnstitutu, Bakı, Azərbaycan \\ Ifirudinasgarov@gmail.com, ${ }^{2}$ rahasanova@gmail.com
}

\begin{abstract}
Xülasə- Hazırda kitabxana-informasiya mühitində kitabxanaçıların və oxucuların tələblərinə cavab verən Kitabxana İdarəetmə Sisteminin (KİS) seçilməsi ən vacib məsələlərdən biridir. Məqalədə AMEA İnformasiya Texnologiyaları İnstitutunda totbiq edilən Alephino KİS haqqunda molumat verilir. Həmçinin kitabxana işinin yüksək səviyyədə təşkili və KİS-lərdə fərdi məlumatların konfidensiallığının qorunması məsələləri analiz edilir.
\end{abstract}

Açar sözlor- e-kitabxana, Kís, Alephino, fordi molumatlar, informasiya tohlükosizliyi

\section{GİRIŞ}

$\mathrm{XX}$ əsrin sonu və XXI əsrin əvvəllərində internetin yaranması və elmi-texniki inkişaf bəşəriyyətin sənaye cəmiyyəti mərhələsindən informasiya cəmiyyəti mərhələsinə keçidini təmin etdi. Müasir informasiya cəmiyyətinin əsas vəzifəsi yaşından, dilindən, dinindən, irqindən, zaman və məkandandan asılı olmadan bütün insanların informasiya tələbatını ödəmək, onların arasında sosial kommunikasiya mühiti yaratmaq, bilik və düşüncələrini ictimaiyyətə çatdırmaqdır [1].

Virtual məkanda informasiya bolluğu şəraitində istifadəçi əldə etdiyi üstünlüklərlə bərabər bir sıra problemlərlə də üzləşə bilər. Baxmayaraq ki, bəşəriyyət yaranan gündən informasiya təhlükəsizliyi mövcud olmuşdur, müasir dövrdə texnikanın sürətli inkişafi ilə bu təhlükəsizlik problemlərinin daha da qabarıq şəkil almasına səbəb olmuşdur. Belə ki, keçən əsrin sonralarına qədər kağız üzərində olan informasiyanın idarə edilməsi, qorunması çox asan idisə, bu gün virtual məkanda, elektron daşıyıcılarda informasiyanın qorunması çox mürəkkəb məsələlərdəndir [2].

İnformasiya təhlükəsizliyinin problemlərindən biri fərdi məlumatların mühafizəsi ilə bağlı olan məsələlərdir. Fərdi məlumatlar haqqında Azərbaycan Respublikasının qanununa əsasən fərdi məlumatlar toplandığı andan mühafizə olunur və bu məqsədlə daxilolma (əldə olunma) növünə görə konfidensial və açıq kateqoriyalara bölünür. Konfidensial fərdi məlumatlar qanunvericilikdə nəzərdə tutulmuş tələblərə uyğun səviyyədə mülkiyyətçi, operator və bu məlumatlara giriş hüququ olan istifadəçilər tərəfindən mühafizə olunmalıdır. Konfidensial fərdi məlumatlar qanunla müəyyən olunmuş hallar istisna olmaqla, üçüncü şəxslərə yalnız subyektin razılığı əsasında verilə bilər. Açıq fərdi məlumatlar kateqoriyasına müəyyən olunmuş qaydada adsızlaşdırılmış, subyekt tərəfindən açıq elan olunmuş və ya ümumi istifadə üçün yaradılmış informasiya sisteminə subyektin razılığ 1 ilə onun barəsində daxil edilmiş məlumatlar aiddir. Şəxsin adı, soyadı və atasının adı daimi açıq fərdi məlumatlardır. Açıq kateqoriyalı fərdi məlumatların konfidensiallığının təmin edilməsi tələb olunmur [3].

\section{KİS FӘRDİ MӘLUMATLARIN TOPLANDIĞI SISTEM KIMI}

Fərdi məlumatlar müasir dövrdə vətəndaşlara elektron xidmət göstərən demək olar ki, bütün dövlət və özəl müəssisələrin sistemlərində toplanılır. Fərdi məlumatların müxtəlif formada toplandığı sistemlərə elektron tibb sistemlərini, kadrlar sistemini, bank sistemlərini, təhsil ilə bağlı sistemləri və s. nümunə göstərmək olar. Bu kimi sistemlərə həmçinin, elektron kitabxanalarda tətbiq edilən Kitabxana İdarəetmə Sistemləri də daxildir.

Kitabxana konsepsiyası yarandığı vaxtdan bu günə kimi insanların informasiya tələbatının ödənilməsi və informasiyanın gələcək nəsillərə ötürülməsi funksiyasını yerinə yetirir. Hazırda kitabxanalar vətəndaş cəmiyyətinin əsas göstəricisi olan qlobal informasiya mühitinin, beynəlxalq, milli və regional səviyyədə informasiya mübadiləsi sistemlərinin yaradılmasında, informasiyanın əmtəəyə çevrilməsində aparıcı rol oynayir.

Dünya təcrübəsi göstərir ki, kitabxana proseslərinin avtomatlaşdırılması - yüksək ixtisaslı kitabxanaçıların və proqramçıların birgə fəaliyyətinin nəticəsi kimi informasiya kommunikasiya texnologiyalarının (IKKT) tətbiqi ilə həyata keçirilən mürəkkəb məsələlərdən biridir. Qeyd edək ki, kitabxana proseslərinin kompleks şəkildə avtomatlaşdırılması Kitabxana İnformasiya Sistemlərinin yaradılmasını nəzərdə tutur. İnformasiyanın sürətlə artdığı və yeniləndiyi bir şəraitdə Kitabxana İnformasiya Sistemlərinin yaradılmasının əsas məqsədlərindən biri IKKT-nin imkanlarından istifadə etməklə yerləşdiyi məkandan və zamandan asılı olmayaraq kitabxanalar və oxucular arasında informasiya mübadiləsinin həyata keçirilməsidir. Həmçinin, buraya oxucuların sorğularına operativ münasibət bildirilməsi də daxildir. 
Avtomatlaşdırma prosesini həyata keçirmək üçün ilkin olaraq proqram təminatı seçilməlidir. Proqram təminatının seçimi zamanı IKKT bazarında mövcud proqram təminatları analiz olunmalı və onların içərisindən ən optimalı müəyyənləşdirilməli və ya uyğun proqram təminatı mövcud olmadıqda yeni proqram təminatı hazırlanmalıdır. Kitabxana proseslərini kompleks şəkildə avtomatlaşdırmaq üçün yaradılmış proqram təminatları bir çox hallarda Avtomatlaşdırılmış Kitabxana İnformasiya Sistemləri adlandırılır. Hal-hazırda daha çox inkişaf etmiş ölkələrdə Avtomatlaşdırılmış Kitabxana İnformasiya sistemlərini Kitabxana İdarəetmə Sistemləri adlandırırlar [4].

Elektron kitabxana (e-kitabxana) deyərkən oxucunun zaman və məkan anlayışı olmadan istədiyi vaxt kitabxana kataloqundan (elektron kataloq) istifadə etmə imkanının olması başa düşülür. Web OPAC (Online Public Access Catalog) modulu isə oxucuya internet üzərindən kitabxana kataloqundan istifadəyə imkan verir. Ümumiyyətlə, OPAC iki mənada işlənilir: onlayn elektron kataloq və KİS-in biblioqrafik məlumat bazasına müraciəti təmin edən interfeys hissəsi kimi. Məhz bu baxımdan Kitabxana İdarəetmə Sistemlərində Web OPAC modulunun mövcudluğu zəruridir.

Müasir dövrdə dünyada çoxlu sayda müxtəlif ölkələrin istehsalı olan KİS-lər vardır. Bu KİS-lərə ABŞ istehsalı olan Alexandria (1988), Millenium (1990), Mandarin (1995), Virtua (1998), Destiny (2003), Koha (2004), İsrail istehsalı olan Alephino (1986), Rusiya istehsalı olan IRBIS-64 (2000), Kanada istehsalı olan ResourceMate (1993) və s. nümunə göstərmək olar [5].

\section{E-KİTABXANALARDA FORDİ MOLUMATLARIN TӘHLÜKӘSIZZLİK PROBLEMLӘRİ}

E-kitabxanalarda tətbiq edilən Kitabxana İdarəetmə Sistemlərinin layihələndirilməsində, qurulmasında və istismarında ən vacib problemlərdən biri informasiya təhlükəsizliyidir.

Oxucuların e-kitabxana xidmətlərindən tam şəkildə istifadə edə bilməsi üçün ad və soyadlarını, e-poçt ünvanlarını, telefon nömrələrini və identifikasiya edilə bilən digər fərdi məlumatlarını kitabxanaçıya təqdim etməsi lazım gəlir.

Bu informasiya "üçüncü tərəf” dediyimiz hakerlərdən və bu məlumatları kitabxana ilə əlaqəsi olmayan məqsədlər üçün istifadə etmək istəyən şəxslərdən qorunmalıdır.

E-kitabxananın kitabxana oxucularının demoqrafik verilənlərindən başqa, aşağıdakı fərdi məlumatlarına da girişi vardir [6]:

- müddətli əldə etdiyi informasiya resursları (İR);

- məsləhət aldığı nəşrlər haqqında məlumatlar;

- onlayn axtarış məlumatları;

- $\quad$ sifariş etdiyi İR sorğularının siyahıları və s.

E-kitabxanalarda oxucular haqqında geniş həcmli fərdi məlumatlar toplanılır. Bu məlumatlar oxucu və kitabxanaçı arasında konfidensial hesab olunsa da, kitabxana tərəfindən “üçüncü tərəf'ə (hüquq-mühafizə orqanlarına, kommersiya təşkilatlarına və s) təqdim edilməsi üçün arxivləşdirilə bilər. Kitabxanalarda fordi məlumatların konfidensiallı̆̆ının qorunmasına dəyər verilsə də, bu digər məsələlərlə müqayisədə əhəmiyyətli hesab edilmir [6].

Amerika Kitabxanalar Assosiasiyası 1960-cı illərin əvvəlində Etika Kodeksində fərdi məlumatların təhlükəsizliyi ilə bağlı tələblər nəzərə çatdırılmışdır [7]. Etika Kodeksində bir çox vəzifələr müəyyən edilir. Məsələn, "Hər bir kitabxana istifadəçisinin axtarılmış və ya alınmış informasiya üzrə və məsləhət alınmış, müvəqqəti götürülmüş, əldə edilmiş və ya ötürülmüş resurslar üzrə gizlilik və konfidensiallıq hüquqlarının qorunması belə vəzifələrdəndir"

Amerika Kitabxanalar Assosiasiyasının 2002-ci ildə nəşr etdiyi və 2014-cü ildə isə yenilədiyi "Gizlilik və konfidensiallıq üzrə suallar və cavablar" adlı sənəddə ekitabxanalarda və KİS-lərdə oxucuların konfidensial məlumatlarının necə işlənməli olduğunu və bununla bağlı təcrübəni nümayiş etdirir [8].

Qeyd etmok lazımdır ki, AMEA İnformasiya Texnologiyaları İnstitutunun elektron kitabxana mərkəzində tətbiq edilən Alephino KİS-də fərdi məlumatların konfidensiallığı nəzərə alınmışdır.

Alephino proqram təminatı 1986-c1 ildə İsraildə əsas1 qoyulan, KİS-lərin hazırlanması və inkişaf etdirilməsi ilə məşğul olan Exlibris şirkəti tərəfindən yaradılmışdır. Bir neçə avropa dillərində fəaliyyət göstərən, sadə interfeysə malik olan bu Kitabxana İdarəetmə Sistemi 90 ölkənin 6000-dən çox kitabxanasında beynəlxalq səviyyədə tətbiq olunur.

Bu KİS-in böyük kitabxanalarda tətbiq olunan universal və uğurlu Aleph sistemi ilə sıx əlaqəsi onun kitabxana dünyasının ən son imkanlarına əlyetərliyini təmin edir. Alephino standart XML mübadilə formatı istifadə edən açıq əlaqələr sistemi kimi müxtəlif inteqrasiya mühitlərinə fərqli adaptasiya versiyalarına məxsusdur. Burada sistemə daxil edilmiş sənədlərin və siyahıların individual qaydada formatlaşdırılması da mümkündür.

Bu kitabxana idarəetmə sistemində də digər qərb ölkələri istehsalı olan KİS-lərdə olduğu kimi oxucuların e-kitabxanadan istifadə tarixçəsini, müxtəlif zamanlarda əldə olunmuş informasiya resurslarının hansı fərqli oxucular tərəfindən əldə olunduğu və s. kimi məlumatları izləmək mümkün deyil. Belə ki, KİS e-kitabxanadan istifadə edən oxucuların fərdi məlumatlarının konfidensiallığını qorumaq məqsədi ilə ayrıayrı modullarında bu məlumatlara girişi kitabxanaçının özünə belə mümkünsüz edir. Yəni KİS yaradılarkən oxucuların fərdi məlumatlarının “üçüncü tərəf'ə ötürülməsinin, müxtəlif yollarla ələ keçirilməsinin qarşısını almaq üçün qeyd etdiyimiz funksiyaları proqram təminatına əlavə edilməyib [9].

\section{NəTİCO}

Araşdırmalar nəticəsində məlum olmuşdur ki, KİS-lərdə istifadəçiyə nəzərən statistik məlumatların tam dolğun çıxarılması mümkün deyildir. Buna baxmayaraq sistemlərdə 
hər hansı informasiya resursuna (kitab, jurnal və s.) aid bütün statistik məlumatları (məsələn, bu resursa ay ərzində neçə dəfə müraciət olunub və s.) əldə etmək mümkündür. Lakin hər hans1 bir resursu istifadə etmiş oxucuların tam siyahısına baxdıqda sistem yalnız həmin resursu istifadə edən ən son oxucunun adını görməyə imkan verir. Ümumiyyətlə, ABŞ və qərb ölkələrində oxucunun kitabxanadan istifadə tarixçəsinin izlənilməsi fərdi məlumatlara müdaxilə kimi qiymətləndirilir və təhlükəsizlik baxımından bu prosesi çətinləşdirilir. Bu ilk növbədə oxucunun fərdi məlumatlarının "üçüncü tərəf"ə ötürülməsinin qarşısını almaq üçündür. Lakin fövqəladə hallarda KISS-dən oxucu haqqında fərdi məlumatlar əldə edilə bilər. $\mathrm{Bu}$ yalnız server administratoru tərəfindən loq faylları təhlil etməklə mümkündür. Qeyd etmək lazımdır ki, bu imkan hər KİS-də mövcud olmaya bilər.

Hər bir müəssisə və ya təşkilat mövcud beynəlxalq Kitabxana İdarəetmə Sistemləri içərisindən öz kitabxanasının fəaliyyət sahəsinə uyğun olanını seçib tətbiq etməlidir. Bu mümkün olmadıqda isə təşkilatın fəaliyyətinə xas kitabxana proseslərini nəzərə almaqla yeni KİS yaradılmalıdır. Lakin bu proqram təminatı hazırlanarkən informasiya təhükəsizliyi məsələlərinə ciddi yanaşılmalı və fərdi məlumatların konfidensiallığı mütləq şəkildə qorunmalıdır.

\section{İSTINADLAR}

[1] R. M. Oliquliyev, R. Ș. Mahmudov, "İnternet cəmiyyətin inkișafının hərəkətverici qüvvəsi kimi," İnformasiya cəmiyyəti problemləri, 2016, №1, səh. 35-45.

[2] R. M. Oliquliyev, Y. N. İmamverdiyev, R. Ş. Mahmudov, "İnformasiya təhlükəsizliyinin multidissiplinar elmi-nəzəri problemləri," İnformasiya cəmiyyəti problemləri, 2017, №2, səh. 32-43.
[3] Fərdi məlumatlar haqqında Azərbaycan Respublikasının qanunu. http://www.e-qanun.az/framework/19675

[4] F. Osgərov, "E-kitabxanalarda tətbiq olunan proqram vasitələrinin analizi: üstünlükləri və çatışmazlıqları," Proqram mühəndisliyinin aktual elmi-praktiki problemləri I respublika konfransının materialları, səh. 213-214, Bak1, 17 may 2017-ci il.

[5] www.capterra.com/library-automation-software/

[6] Y.N. İmamverdiyev "IDEA4SP: E-kitabxanalar üçün informasiya təhlükəsizliyi modeli," İnformasiya cəmiyyəti problemləri, 2017, №2, səh. 74-83.

[7] American Library Association Code of Ethics, http://www.ala.org/advocacy/proethics/codeofethics/codeethics

[8] Questions and Answers on Privacy and Confidentiality, http://www.ala.org/advocacy/intfreedom/librarybill/interpretations/qaprivacy

[9] Alephino v4.0. http://www.ex-lh.hu/site/index.php/en/alephino-4-eng

\section{SECURITY ISSUES OF PERSONAL INFORMATION IN ELECTRONIC LIBRARIES}

Firudin Asgarov ${ }^{1}$, Rahila Hasanova ${ }^{2}$

${ }^{1,2}$ Institute of Information Technology of ANAS, Baku, Azerbaijan Ifirudinasgarov@gmail.com, rrahasanova@gmail.com

Abstract - Today selection of a Library Management System (LMS), that meets the needs of librarians and readers is one of the most important issues in the library and information environment. The article provides information on Alephino LMS applied in the Institute of Information Technology of ANAS. It is also analyzed organization of library work in high level and protection of the confidentiality of personal information in the LMS.

Keywords - e-library, LMS, Alephino, personal information, information security 